\title{
The Introduction of English Education Culture under the Guidance of Patriotic Cultural Identity Education
}

\author{
Wang Chengsheng \\ Department of Foreign Languages, Yangtze University of Arts and \\ Sciences, Jingzhou, Hubei, China, 434020
}

\begin{abstract}
With the increase of economic trade and cultural exchanges, the importance of English is becoming more and more prominent. In the face of the erosion of foreign culture, colleges and universities should take corresponding measures with patriotism and cultural identity education to increase cultural introduction in English education and to improve the status quo of lacking of the cultural identity. Keywords: patriotism; cultural identity; purpose; English education

China is a multi-ethnic country, its development not only to unite the multi-ethnic forces to achieve the great rejuvenation of the Chinese nation, but also with other countries to maintain friendly relations. With the development of globalization, English, as a common language, plays an important role in international communication. Faced with the invasion of foreign culture, China's patriotism education is facing enormous challenges. In the new historical conditions, colleges and universities in the development of English education should actively carry out patriotic cultural identity education, building a patriotism as the core value system, enhancing national cultural identity, to integrate cultural introduction and English education together.
\end{abstract}

\section{The meaning of patriotic cultural identity education}

Patriotism is the crystallization of the wisdom of our people, so every Chinese children should remember the important spirit. The recognition of patriotism is divided into political identity and cultural identity. Political identity is the 
recognition and acceptance of national political system and concept. Cultural identity refers to the recognition and acceptance of citizens' mainstream culture and values. Whether it is a multi-ethnic state or a single nation state, whether it is a long history or just established, national identity is a long-term process, plays a decisive role in national development, will change with the development of the times. Cultural identity education is an important challenge facing all countries in the world. If there is the lack of cultural identity education, it will bring serious consequences to the country's development.

The social core value system has a far-reaching impact on people's values, ways of thinking and behavior norms. The goal of carrying out patriotic cultural identity education is to instill the values of national interests into the values of citizenship, and reflected in the specific practice [1]. Therefore, patriotic cultural identity education should make full use of political means to enhance the citizen's national consciousness and the Chinese nation's values, and the Constitution as the basis to build a patriotic cultural identity as the core of the strategic system. In education, we must take patriotism as the purpose, in the face of globalization and the development of the independence of citizens to enhance the status quo, and we must use cultural identity to maintain our social stability and unity, and promote the smooth development of political system.

\section{The crisis of patriotic cultural identity education}

With the globalization and the change of the market economy system, the patriotism of our country suffers great crisis, the spirit of patriotism of the contemporary college students is seriously missing. The causes of this phenomenon fundamentally lie in the lack of cultural identity education. Some scholars have pointed out that cultural identity crisis is the core crisis of contemporary China. Patriotic cultural identity crisis refers to the lack of individual or group patriotic culture. The crisis of patriotic cultural identity of contemporary college students is mainly manifested in the following aspects.

With the deepening of the process of reform and opening up, all kinds of cultural trends have poured into the door of our country. Cultural collision and communication, not only provides a wide range of cultural choices, but also causes other cultures in our culture penetration, so that our culture is facing severe challenges. Foreign culture has a strong attraction to college students. In foreign culture, college students are more inclined to choose Western culture, longing for Western liberalism, so that students lack the national self-esteem and self-confidence. Meanwhile, many college students know little about our national culture, and even indifferent to our national culture, resulting in the formation of nihilistic attitude in college students, so college students lack patriotism and spirit [2].

Under the influence of feudalism and centralization, there was no problem of cultural identification, home, country and culture in ancient China. With the implementation of the policy of reform and opening up, China has gradually integrated into the tide of world development. The development of economy 
makes the western capitalism idea expand constantly, and the socialist form of our country has been violently affected. College students lack of patriotic cultural identity, while pursue Western liberal ideas, so their concept of socialism is not firm. At the same time, the influence of the market economic system and hedonism in the university group gradually are spreading, so there is college students utilitarian consciousness and strong selfishness. These factors make university students reduce mainstream culture recognition.

In the new era, hedonism, utilitarianism has gradually replaced the moral values of traditional values. First of all, the development of the market economy is gradually enhancing the sense of competition for the citizens, the main values of the community is shifting to egoism, and college students individualism has gradually over the top of collectivism. In our traditional culture, the patriotism core value is the collective supreme, the individual must strictly obey the collective leadership, but the contemporary university student value view and the traditional value view are contrary, leading the university student patriotism spirit to be lacking. Second, some college students considering the feasibility of a matter, mainly depend on the interests of its representatives. This utilitarianism can't comply with patriotism advocated by the spirit of devotion. Third, college students' value orientation is diversified, and the evaluation results of the same thing are different. The value standard of the traditional culture is unified, the patriotism idea is under this unified standard, but the evaluation standard of the contemporary university student is diversified, therefore, the spirit of the patriotism of college students is seriously missing.

With the development of culture and entertainment, entertainment culture is full of people's life. Market demand has become the vane of cultural development. Under the influence of market economy, entertainment culture makes people pursue short-term sensory stimulation, which results in the lack of cultural identity. The formation of college students' outlook on life and values will be affected, the national sense of crisis will be seriously lacked, and patriotism will gradually be replaced by hedonism.

\section{The principles and content of English education and culture}

The development of globalization makes the importance of English teaching more prominent. The introduction of English education and culture for the purpose of the patriotic cultural identity education, must follow the following three principles: relevance, practicality, the principle of gradual and orderly progress. English culture introduction should be strictly in accordance with the implementation of the above three principles, so that the introduction of English education and culture will harvest a good effect.

The principle of relevance has strict requirements on the content of English education for teachers. The teaching contents must meet the requirements of the outline. The content of cultural introduction should be related to the content of English teaching. Here, the relevance principle can be seen as the expansion of teaching materials. In the introduction of English education and culture, it is 
necessary to make full use of English teaching materials, so that they can in accordance with the teaching and learning activities. The requirements of relevance principle of English education and cultural introduction include that language teaching is the main aspect, while cultural teaching is supplement [3].

The practical principle requires that the contents of the English education culture should be related to the students' learning content. The new teaching content should be closely related to the students' real life. In fact, English communication is easily influenced by many cultural factors. In English teaching, teachers should explain the contents in detail, so that students can apply their knowledge, which will avoid the problem that students are difficult to understand the abstract learning content, while English learning and cultural education combined to attract students interest in learning to achieve a virtuous circle.

The principle of step by step is the stage principle of the introduction of English education culture. When the culture is introduced, the new content should meet the needs of students' learning and personality characteristics. The content of study will be changed from abstraction to essence, so as to expand English culture. Only by fully grasping the above principles, English education and culture can be carried out smoothly.

Culture is a complex concept, and culture can be divided into narrow sense and generalized one. Narrow sense of culture refers to the national way of life, generalized culture refers to the nation or its representative achievements and contributions. In English education, the contents of cultural import can be divided into the following.

First, the context-related factors, such factors and people's lives are closely related, such as social customs, lifestyles and so on. In real life, English learners often ignore the social culture behind English. In English communication, English greetings and appellations are transformed directly, which leads to the occurrence of grammatical errors. The difficulty of English teaching is how to choose the right language at the right time and place.

Second, the values associated with the factors. The formation of values is closely related to the culture and history of the nation. Values are often regarded as the core of culture and have a profound impact on people's way of life and ways of thinking. In real life, people often values as the standard of things evaluation. China is a socialist country, collectivism in social life plays an important role. In the capitalist countries, the individualism is supreme. Therefore, there are differences between the Chinese and foreigners in the ways of expression.

Third, non-verbal factors. In real life, people often will be language and body language closely together. Body language mainly through a variety of actions to express different meanings, to promote the understanding of both sides. The same expression in different cultures may have different meanings, therefore, to in-depth study and explore the cultural meaning behind the language [4]. 


\section{The necessity of the introduction of English education and culture}

The introduction of English education culture can promote the communication between different cultures and promote the integration of culture.

The development of higher education should serve the construction of socialism with Chinese characteristics and cultivate the patriotism of students. Under the influence of the preconceived principle, the students are easy to accept the foreign culture, which easily lead to a crisis of Chinese cultural identity. Therefore, English education should strengthen the proportion of cultural identity education, so that English professional learning to provide services for the cause of socialism.

Only two-way communication can establish a good communication bridge. In English education, universities attach too much importance to the study and understanding of foreign culture, ignoring the study of Chinese culture, leading to poor understanding of Chinese culture, resulting in cultural identity is missing.

Since China's reform and opening-up policy, more and more economic cooperation, cultural exchanges gradually deepened, the importance of crosscultural communication is increasing. In English education, one should correctly understand the differences between cultures, but to look down on their own[5].

\section{The methods of introduction of English education culture}

In English teaching, universities often attach importance to the study of Western culture, ignoring the cultivation of national culture, so that students lack patriotism, lack of recognition of traditional Chinese culture. Therefore, colleges and universities in English teaching, learning Western culture at the same time, pay attention to the study of national culture, increase the content of patriotism in the proportion of English teaching, cultivating students' national sense of honor, personal development and national development closely.

China has some teachers will be patriotic cultural identity education infiltration in English teaching activities, and harvest a good learning effect. For example, Professor Ding Wangdao at the Beijing Foreign Studies University, the Chinese culture interspersed in the English teaching; Peking University Professor $\mathrm{Gu}$ Zhengkun will be in the Western cultural differences in contrast, for English teaching, attracting a large number of students Learn. From the above examples can be found that students have gradually recognized the importance of cultural import.

In English education, colleges and universities should actively adjust the English curriculum system, increase the proportion of patriotic cultural identity education in the course of study, improve the national culture of credit, so that patriotic cultural identity education in English education in a place. In addition, colleges and universities can collect excellent teaching programs, in English teaching materials to increase the content of national culture. Such materials can 
expand students' horizons, so that students learn English more comprehensive [6].

Extracurricular practice activities are an important complement to classroom teaching, but also an important way to achieve the goal of English education. College English activities are varied, such as English speech contest, debate contest, English song contest, in these extracurricular activities, can appropriately increase the proportion of national culture, in the exchange process, promote the exchange and integration of Western culture. In English education, colleges and universities should pay attention to the introduction of national culture, patriotism, cultural identity education for the purpose of promoting students to master Chinese culture and understanding, helping students develop a correct outlook on life and values.

\section{References:}

[1] ZhangTaiqi, Wei Xiaoliu. National Identity-the Core Value Orientation of Patriotism Education of Minority College Students in Xinjiang [J]. Journal of Tarim University, 2014,03: 106-111.

[2] Yue Yongjie, Zhang Wenbin. Analysis of Patriotic Education in National Institutions of the Four Cultural Paths [J]. Heilongjiang Nationalities Series, 2015,06: 164-168.

[3] Peng Xia. Higher Vocational Education in the Meaning of Cultural Introduction [J]. Asia-Pacific Education, 2016,07:146-147.

[4] Su Tingting. The Issue of Vocational Education in English Culture [J]. Time Education, 2014,20: 95.

[5] Guo Huanping, Ren Quanqing. Chinese Culture Introduction and Cultural Identity in English Education [J]. Journal of Lvliang University, 2014,05: 80-82.

[6] Sun Man. Contemporary Educational Technology under the English Classroom Culture into the Discussion [J]. Son (on the middle), 2015,21: 114. 